\title{
EMULSOMES: AN EMERGING VESICULAR DRUG DELIVERY SYSTEM
}

\author{
*Rajesh Kumar, Nirmala, SL Hari kumar \\ Rayat and Bahra Institute of Pharmacy, Mohali Campus, Sahauran,Punjab, India \\ *Corresponding Author's Email: rajeshguleria83@gmail.com
}

\begin{abstract}
The oral route is the easiest, cost effective, and most vital method for drug administration. Therefore, improvement of dosage forms, mainly for the prolonged release purpose has been a challenge for scientists. Vesicular drug delivery systems are developed with a purpose to overcome problems coupled with the drugs such a poor bioavailability, protection from harsh gastric environment, and from gastric enzymes, which degrade the drug. Vesicular drug delivery systems such as liposomes, emulsions, niosomes, proniosomes, solid lipid-nano particles, ethosomes, nanoparticles, and pharmacosomes, etc have gained much attention, but emulsomes have rouse as system, which bypasses many disadvantages associated with other systems, developed as novel lipoidal vesicular system with internal solid fat core surrounded by phospholipid bilayer. This technology is designed to act as vehicle for poorly soluble drugs. The drug is enclosed in the emulsomes and provide prolong existence of drug in systemic circulation. Furthermore, emulsomal-based formulations of genetic drugs such as antisense oligonucleotides and plasmids for gene therapy that have clear potential for systemic utility are increasingly available. This review addresses the concept of emulsomal drug delivery system, summarizes the success of emulsomes for the delivery of small molecules, and special attention has been paid to its formulation design, advantages, biopharmaceutical aspects, stability aspects, and various aspects related to drug delivery including future aspects.
\end{abstract}

Keywords: Controlled oral drug delivery, emulsomes, oral bioavailability, vesicular drug delivery

\section{INTRODUCTION}

In past few decades attention has been focused on development of vesicular drug delivery system. Nowadays, vesicles as a carrier system have become the vesicles of choice in drug delivery and lipid vesicles are established to be valuable in immunology, membrane biology, and diagnostic technique, an d most importantly in genetic engineering. Lipids are referred to a group of naturally occurring molecules which include fats, waxes, sterols, fatsoluble vitamins (such as vitamins A, D, E, and K), as well as mono-glycerides, triglycerides, phospholipids. Lipids may be broadly defined as hydrophobic or amphiphilic small molecules; the amphiphilic nature of some lipids allows them to form structures such as that of vesicles. ${ }^{1}$ Therefore, researchers recognize the potential of the lipids for delivering soluble materials for extended periods. ${ }^{2}$ Vesicles are unilamellar or multilamellar spheroid structures composed of lipid molecules assembled into bilayers, Because of their capacity to carry a number of drugs, vesicular delivery systems have been widely investigated for their prospective application in pharmaceutics such as drug delivery ${ }^{3-5}$ for drug targeting, ${ }^{6}$ forcontrolled release, ${ }^{7}$ or for increasing solubility. ${ }^{8}$

Emulsomes is a novel lipoidal vesicular system with an internal solid fat core surrounded by a phospholipid bilayer. Structure of emulsomes is shown in [Figure1]. Emulsomal formulations composed of solid lipid core material and stabilized by cholesterol and soya lecithin. The drug is loaded followed by sonication to produce emulsomes of small size. ${ }^{9}$ The polymer used for core material should be solid at room temperature $\left(25^{\circ} \mathrm{C}\right) .{ }^{10}$ The high soya lecithin concentration stabilized the emulsomes in form of $\mathrm{O} / \mathrm{W}$ emulsion. ${ }^{11}$ These fat cored lipid particles are dispersed in an aqueous phase. These systems are often prepared by melt expression or emulsion solvent diffusive extraction.

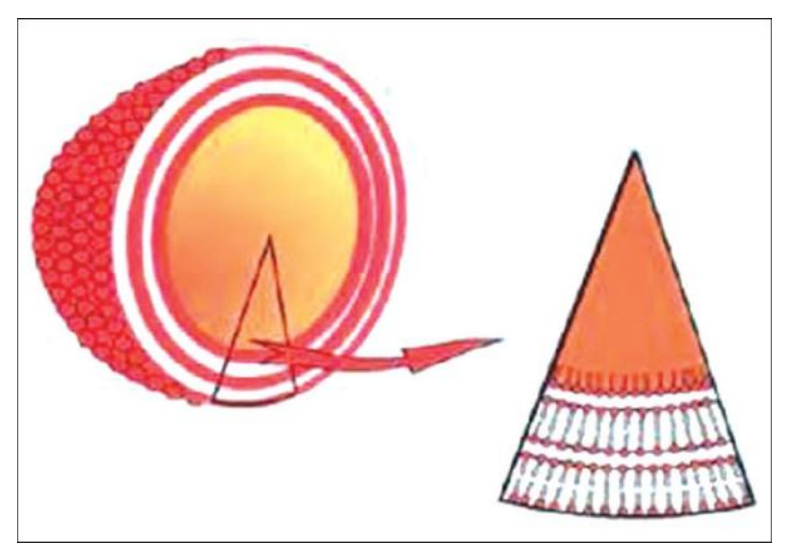

Figure 1: Structure of emulsome

Emulsome represents lipid-based drug delivery systems with broad variety of therapeutic applications particularly for drugs that are poor aqueous soluble. $\frac{12}{\text { Emulsomes }}$ consist of microscopic lipid assembly with a polar core, which contains water insoluble drugs in the solution form without requiring any surface active agent or co-solvent. Beside the other vesicular formulations, emulsomes are much stabilized and nano range vesicles. It is a new emerging delivery system and therefore could play a fundamental function in the effective treatment of lifethreatening viral infections and fungal infections such as hepatitis, HIV, Epstein-Barr virus, leishmaniasis, etc. appear promising for the treatment of visceral leishmaniasis specifically and hepato-splenic candidiasis. ${ }^{9-}$

${ }^{11}$ Furthermore, in systemic fungal infections, the systems can be used for rapid loading of reticuloendothelial system organs with the incorporated drug for the complete eradication of the intracellular pathogens. Emulsomes 
could be utilized in order to improve oral controlled delivery of drug, vaccine, and bioamcromolecules. It is due to the fact that they are nano sized in range and could be utilized for the intravenous route. Moreover, emulsomes could represent a more economical alternative to current commercial lipid formulations for the treatment of viral infections and fungal infections. Emulsomes provide a controlled and sustain release of drug. In comparison to the liposomes, emulsomes provide a prolong release of drug upto 24 hours, whereas liposomes have shown release upto 6 hours. ${ }^{12-14}$ Emulsomes are nano size range in comparison to other vesicular delivery system such as niosomes, pharmacosomes, and ethosomes. Due to the reduced size they can be used to enhance bioavailability to drug and as the best carrier for the intravenous drug delivery as well as oral drug delivery.

\section{Advantages of emulsomes}

Emulsomes defend drug from harsh gastric environment of stomach before oral administration because the drug is enclosed in the triglyceride lipid core. This hypothesis could be supported by the fact that gastric $\mathrm{pH}$ and gastric enzymes are unable to hydrolyze triglycerides.

Emulsomes increase the solubility and bioavailability of poorly aqueous soluble drugs. They are composed of triglycerides and form micelles or are organized as lipid bilayers with the hydrophobic tails lined up against one another and the hydrophilic head-group facing the water on both sides. These unique features make phospholipids most suitable to be used as excipients for poorly water soluble drugs.

Emulsomes are composed of lipid core. Lipids are used to develop oral controlled delivery of drug. The wide spread adoption of lipid based strategies for enhancing drug exposure is limited.

Emulsomes are economical alternative to current commercial lipid formulations because they reduce the dosing frequency of drug.

Emulsomes-based system showed excellent potential for targeting. The formulations could significantly modify providing prolonged action at comparatively low drug doses thereby reduction in the toxicity problem due to complimentary localization of the drug in target cells.

They provide significantly modify the pharmacokinetics of drugs.

Also, they resist development of multi drug resistance, often associated with over expression of a cell membrane glycoprotein, which cause efflux of the drug from the cytoplasm and results in an ineffective drug concentration inside the cellular compartment.

\section{Mechanism of emulsome sabsorption}

Emulsomes have structural similarity with the chylomicrons (natural lipoprotein of the body) and consequently expected to mimic these lipoproteins in behavior. These diminutive lipids like particles are frequently taken through endogenous lipid absorption mechanism through enterocytes of GIT tract. ${ }^{14}$ Intestinal absorption of long-chain triglyceride from enterocytes is a complex incident that includes the co-ordination of synthesis of apolipoproteins and lipids and their intracellular assembly into mature lipid-containing particles. ${ }^{15}$ The major digestive products of triglyceride are monoglycerides and free fatty acids. These are absorbed into the enterocytes via passive diffusion and transported within the enterocyte to the endoplasmic reticulum (ER), where biosynthesis of complex lipids to form triglyceride takes place. $\frac{16}{}$ The precursors of chylomicrons, termed prechylomicrons, are synthesized in the ER and Golgi apparatus. Lipoproteins are made in the ER and then transported to the Golgi. The chylomicrons then migrate to the lateral membrane of enterocytes and are exocytosed, and the triglyceride-rich lipoproteins are discharged into the intercellular space. ${ }^{17}$ Lipid-based excipients can influence oral absorption via various physiological effects such as retarded gastric emptying, $\frac{18}{2}$ stimulating bile flow, and secretion of pancreatic juice increasing the membrane lipid fluidity or acting directly onto enterocytes-based drug transport and disposition. ${ }^{19-21}$

\section{Emulsomal formulation}

\section{Lipidcore}

An essential component of emulsomes is an internal hydrophobic core or lipid core comprises lipid, which exhibits solid or lipid crystal phase or mixed solid and liquid crystal phase at room temperature $\left(25^{\circ} \mathrm{C}\right)$. There are abundant lipids or lipid like excipients available commercially. All of which are collectively called lipids in the pharmaceutical field. $\stackrel{22}{T}$ The lipid used may be single or mixture of lipids. They are fatty acids and their derivatives or substances biosynthetically and functionally related to these compounds. ${ }^{23-25}$ Lipids are generally insoluble in water and are often identified by their fatty acid composition, melting point, and hydrophilic-lipophilic balance (HLB). Lipids with low HLB and high melting point are suitable for sustained release. Whereas, the semisolid excipients and those with high HLB serve as immediate release and bioavailability enhancement excipients. ${ }^{26-29}$ Triglycerides which are solid at $25^{\circ} \mathrm{C}$ are found to be appropriate core material because these lessen the acceptable storage life of $\mathrm{o} / \mathrm{w}$ emulsion. The triglycerides are used for preparation of emulsome composed of un-branched fatty acid with chain length in the $\mathrm{c}-10$ to $\mathrm{c}-18$ range. $\underline{30}$

\section{Antioxidant}

The lipid core of emulsome particles of this invention optionally may contain one or more antioxidant. The preferred antioxidant is a-tocopherol or its derivative, which are members of vitamin $E$ family. Other antioxidants include butylated hydroxytouline (BHT). Antioxidants lessen the formation of oxidative degradation products of unsaturated lipids such as peroxides. The need of antioxidant may be protected by preparing the lipid core form saturatedfattyacid. ${ }^{30}$ 


\section{Negatively charged particles}

Negatively charged lipid particles such as oleic acid or negatively charged phospholipids such as phosphatidic acid, phosphatidylinositol, and phosphatidylsterine can be imparted to emulsomes to raise the zeta potential of the composition, thus stabilizing the particles. Additionally, the incorporation of these negatively charged lipids compounds in emulsomes result in the formation of phospholipids bilayers with opposing charge. $\frac{30}{}$ Thus, increasing the loading aqueous compartment formed by the phospholipids bilayers surround the lipid core. This effect results from the layers aqueous space between the bilayers cause electrostatic repulsion between them. Negative charge reduces the particles aggregation, whichminimizesthecoalescence, floccation,orfusion. ${ }^{31}$

\section{Surfactants}

Selection of surfactant should be done on the basis of Hydrophilic Lipophilic Balance (HLB) value. As HLB is a good indicator of the vesicle forming ability of any surfactant, HLB number in between 4 and 8 was found to be compatible with vesicle formation. ${ }^{32}$ Transition temperature of surfactants also affects the entrapment of drug in vesicles. Spans with highest phase transition temperature provide the highest entrapment for the drug and vice versa ${ }^{33-34}$ The drug leaching from the vesicles is reduced due to high phase transition temperature and low permeability. ${ }^{35}$ High HLB value of Span 40 and 60 results in reduction in surface free energy, which allows forming vesicles of larger size and hence large area exposedtothedissolutionmedium. ${ }^{36-38}$

\section{Phosphatidylcholine}

Phosphatidyl choline is such a major component of lecithin. Phosphatidyl choline has low solubility in water. In aqueous solution its phospholipids can form bilayer sheets, micelles, or lamellar structures, depending on hydration and temperature. This results in a type of surfactant that is usually classified as amphipathic. They are a major component of biological membranes and can be easily obtained from a variety of readily available sources such as egg yolk or soya beans. Depending upon the source from which they are obtained they are named as egg lecithin and soya lecithin. Incorporation of lecithin further enhanced the percent drug entrapment to $96.1 \%$ and leads to vesicles of smaller size due to increase in hydrophobicity, which results in reduction of vesicle size. ${ }^{39}$

\section{Cholesterol}

Cholesterol is essential component of emulsomes as vesicles. Incorporation of cholesterol influences vesicles stability. ${ }^{40-41}$ Concentration of cholesterol plays an important role in entrapment of drug in vesicles. ${ }^{42-43}$ There are reports that entrapment efficiency increase with increasing cholesterol content. It was observed that with very high cholesterol content had a lowering effect on drug entrapment to the vesicles. ${ }^{44}$ This could be due to the fact that cholesterol beyond a certain level starts disturbing the regular bilayer structure leading to loss of drug entrapment. ${ }^{45}$ Various materials used for emulsomal preparation along with their uses are given in [Table 1].

\begin{tabular}{llcc}
\hline Materials & Uses & \multicolumn{2}{c}{ References } \\
\hline $\begin{array}{l}\text { Triglycrides } \\
\text { Cholesterol }\end{array}$ & $\begin{array}{l}\text { Used as hydrophobic lipid core, Lipids with low HLB value provides sustain released formulation. } \\
\text { Incorporation of cholesterol influence vesicles stability, excessive cholesterol leads to }\end{array}$ & {$\left[{ }^{[9,10]}\right.$} \\
& un-stability of the formulation. & {$[32]$} \\
Soya lecithin & Bilayer sheets, micelles or lamellar structures and also increases the entrapment efficiency. & {$[31]$} \\
Stearyl amine & Impart positive charge for target delivery and raised the zeta potential of formulation. & {$[32]$} \\
Antioxidants & Protect the lipids from oxidation or rancidity. & {$[30]$} \\
Surfactants & Provide the highest entrapment for the drug. & {$[29]$} \\
Charged particles Zeta potential of the composition, stabilizing the particles and reduce the particles aggregation. & {$[10,14]$} \\
\hline
\end{tabular}

\section{Methods of preparation}

\section{Lipid film formation (Handshaking method)}

In this method surfactants/lipids are casted as layers of film form their organic solution using flask rotary evaporator under reduce pressure (or by hand shaking) and then casted films are dispersed in aqueous medium. ${ }^{46}$ Upon hydration, the lipids swell and peel off from the wall of round bottom flask at temperature slightly above the phase transition temperature of surfactants used for specific period of time (time of hydration) with constant mild shaking. The mechanical energy is required for the swelling of lipid and dispersion of casted lipid film is imparted by manual by manual hand shaking or by exposing the film to a steam of water saturated nitrogen for 15 minutes followed by swelling in the aqueous medium without shaking. Hand shaking method produce multi lamellar vesicles (MLV) while non shaking method produced large unilamellar vesicles (LUVs). Various methods for emulsomal formulations are shown in [Figure 2]. ${ }^{47}$ 


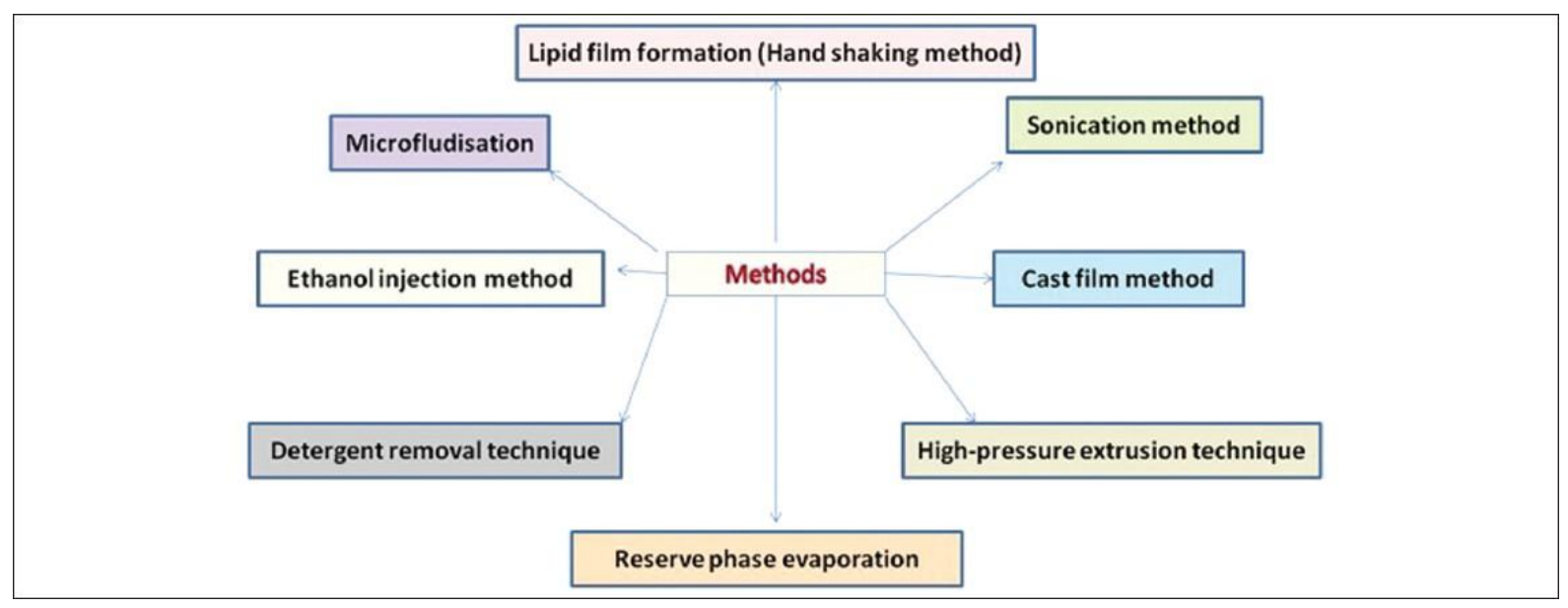

Figure 2: Methods of emulsomal formulation

\section{Reserve phase evaporation}

This technique, so-called 'reverse-phase evaporation' or REV method is comprised of two steps. Prepare a waterin-oil emulsion of phospholipids and buffer in excess organic phase. Remove organic phase under reduced pressure. The two phases (phospholipids and water) are usually emulsified by mechanical methods or by sonication. Removal of the organic solvent under vacuum causes the phospholipid coated water droplets to come together to form a gel-like matrix. Further removal of organic solvent, under reduced pressure, causes the gellike matrix to form into a paste of smooth consistency. This paste is a suspension of LUV. ${ }^{48}$ Drug entrapment efficiencies up to $60-65 \%$ can be achieved by this method. This method was used to encapsulate both small and large molecules. $\stackrel{49}{ }$ The main disadvantage of this method is the exposure of drug to be encapsulated to organic solvents and to mechanical agitation. In this procedure, phospholipids are dissolved in organic solvents such as chloroform, isopropylether, or freon. In order to promote conditions for good emulsification, it may sometimes be required to mix two organic solvents to adjust the density to unity that is closer to the density of aqueous phase. Biologically active molecules such as enzymes, protein pharmaceuticals, and RNA type molecules may undergo conformational changes, protein denaturation, or breakage of DNA strands due to the harsh conditions of organic solvent exposure and mechanical agitation.

\section{High-pressure extrusion technique}

It was demonstrated by several researchers that when MLV are repeatedly passed through very small pore polycarbonate membranes ( 0.8 to $1.0 \mathrm{pm})$ under high pressure the average diameter of the vesicles become progressively smaller reaching a minimum of $60-80 \mathrm{~nm}$ after 5-10 passes. As the average size is reduced the vesicles tend become unilamellar. ${ }^{50-52}$ Similar results are noted by other investigators when MLV were passed through a Microfluidizer. Microfluidizer is an instrument that forces the feed material under high pressure through a narrow orifice. It appears that when MLV are forced through the small orifice, layers of bilayers are removed from the vesicular structure, as if the layers of onion skin are separated when it is peeled. It was also suggested that the mechanism of layer separation is only applicable to vesicles made with positively charged phospholipids and the vesicles that are greater than $70 \mathrm{pm}$ in size. $\underline{53}$

\section{Sonication method}

Solid lipids, cholesterol, and phosphatidylcholine in different molar ratios were taken in a round-bottom flask and dissolved in a minimum quantity of chloroform containing 3 or 4 drops of methanol. To this solution, an accurately weighed quantity of drug was dissolved. The organic solvent was evaporated until complete dryness under reduced pressure using a rotary evaporator to form a thin lipid film on walls of the round bottom flask. ${ }^{54-56}$ The dried film was hydrated with phosphate-buffered saline $\mathrm{pH}$ $7.4(10 \mathrm{~mL})$ and homogenized by ultrasonication for 15 minutes at $40 \%$ frequency to obtain emulsomes of nanosize range. ${ }^{9,10,14}$

\section{Cast film method}

Emulsomes may be prepared by mixing phospholipids and triglycerides in a weight ratio range 0.5:1.0 where in the triglycerides has a solid to liquid phase transition temperature of greater than $25^{\circ} \mathrm{C}$. Suspend the mixture in an aqueous solution at a temperature below the solid to liquid transition temperature otherwise reducing the suspension to yield emulsomes. These emulsomes comprise a nano-emulsion of liquid particles having a mean particle diameter between 10-250 nm usually within the range 20 to $180 \mathrm{~nm}$ usually and frequency within range $50-150 \mathrm{~nm}$. The size range is preferably determined on a weight percentage basis rather preferably are determined on a weight percentage basis rather than a particle number basis. Conventionally the lipid component may be volatile and chemically un-reactive volatile organic solvent such as dichloromethane or diethylether. The solvent is removed typically under reduced pressure in a rotary evaporator or under stream of inert gas. The resulting lipid film is hydrated and dispersed by covering and shaking with an aqueous solution. If the drug component were not included in the organic solution, they may be added to aqueous hydration solution. The lipid suspension or dispersion is then sized typically by high shear homogenizer at a pressure up to 800 bars. $\underline{30}$ 


\section{Ethanol injection method}

This method has been reported as one of the alternatives used for the preparation of small unilammellar vesicles (SUVs). In this method, an ethanol solution of surfactant is injected rapidly through a fine needle into excess of saline or other aqueous medium. ${ }^{57}$ Vaporization of ethanol leads to the formation of vesicles. In the ethanol injection method a narrow distribution of small liposomes (under $100 \mathrm{~nm}$ ) can be obtained by simply injecting an ethanolic lipid solution in water, i.e. in one step, without extrusion or sonication. The ethanol injection method is a suitable technique to obtain the spontaneous formation of emulsomes having a small average radius. ${ }^{58-59}$

Alternatively, the lipid or lipid mixture is dissolved in alcoholic solvent and an aliquot of 200, 500, or $600 \mathrm{~mL}$ fast injected at room temperature, $1 \mathrm{~mL}$ syringe into the dispersant solution, which contains water or saline solution, of $9.8 \mathrm{~mL}$ further diluted to $1: 50,9.5 \mathrm{~mL}$ diluted to $1: 20$ or $9.8 \mathrm{~mL}$ diluted to $1: 17$, respectively. The solution was then vigorously hand-shaken for 20-30 seconds. ${ }^{60-61}$ After that the ethanol solution is fast-injected in a $5 \%$ glucose solution. The vesicles had shown average diameter of about $60 \mathrm{~nm}$ and may be stable foratleastoneweek. ${ }^{62-64}$

\section{Detergent removal technique}

In this method, phospholipids and a detergent are mixed together to form micellar mixtures. Then the detergent removed from the preparation while the micelles progressively become richer in phospholipid content and finally the lipids come together to form single bilayer vesicles. Methods such as dialysis, column chromatography, or adsorption onto bio beads can be used to remove the detergent from the preparation. The dialysis technique was first reported for reconstituting biological membranes solubilized with detergents. $\frac{65}{T}$ This method is applicable for the preparation of emulsomes also. Detergents that are commonly used for this purpose are those that have high critical micelle concentration (CMC). Materials such as sodium cholate, sodium deoxycholate, and octylglycoside and other detergents of high CMC (in the order of $10-20 \mathrm{mM}$ ) are suitable detergents for this work. ${ }^{66}$ In technique, detergent was removed by a flow through dialysis cell from phospholipid detergent mixture. It was reported that this technique yielded homogeneous population of single layered emulsomes with mean diameters of $50-100 \mathrm{~nm}^{67-68}$

\section{Biopharmaceutical aspects}

Emulsomes helps increasing the in-effective luminal drug solubility. The presence of lipids in the GI tract stimulates an increase in the secretion of bile salts and endogenous biliary lipids including phospholipid and cholesterol, leading to the formation of bile salts/phospholipid/cholesterol intestinal mixed micelles and leads increase in the solubilisation capacity of the GI tract. However, exogenous lipids into these bile salts structures either directly or secondary to digestion, leads to swelling of the micellar structures and a further increase in solubilisation capacity. ${ }^{69}$ Therefore, on the stimulation of intestinal lymphatic transportation, lipids may enhance the extent of lymphatic transport and increase bioavailability directly or indirectly via a reduction in first-pass metabolism.

Emulsomes may enhance bioavailability by changing the biochemical barrier function of the GI tract. It is clear that the lipids and triglycrides, which are incorporated in emulsomal preparation may attenuate the activity of intestinal efflux transporters, as indicated by the pglycoprotein efflux pump and may also reduce the extent of enterocyte-based metabolism. ${ }^{70-71}$

Emulsomes may change the physical barrier function of the GI tract. Various combinations of lipids and triglycerides have been shown to have permeability enhancing properties. ${ }^{72-73}$ However, passive intestinal permeability is not thought to be a major barrier to the bioavailability of the majority of poorly water-soluble and lipophilic drugs.

\section{Stability aspects of emulsomes}

Emulsomes have the characteristics of both liposomes and emulsions; provide the advantages of high loading of hydrophobic bioactive compounds in the internal solid lipid core and the ability to encapsulate water-soluble drugs or antigens in the aqueous compartments of surrounding phospholipid layers. ${ }^{14}$ The pharmaceutically stable emulsomes may be formulated in the absence of any ionic or non-ionic non-natural synthetic surfactants or cosurfactants such as polyoxamers, deoxycholate, polysorbates, etc. They are stabilized by the combination of relatively high lecithin content and the use of solid lipid compositions as the core. $\frac{13}{}$ The particle size distribution of emulsomes is based on differential weight percents in the range of $10-250 \mathrm{~nm}$, making them suitable for parenteral administration by adding in water for injection.

Whereas oral vesicular formulations are generally instable, mainly due to leakage and potential destruction in gastric fluids. Emulsomes are a dry free-flowing powder when it comes in contact with water. The stability problems associated with conventional liposomes or other vesicular delivery systems are aggregation, susceptibility to hydrolysis, and oxidation. These problems may be avoided by using emulsomes. ${ }^{10-13}$ Since emulsomes exist as a dry powder and upon hydration they are more suitable for developing sustained release formulations for oral delivery.

Important factor related to stability is zeta potential; the measurement of zeta-potential in electrostatically stabilized vesicles is the key factor to understand the application of the dispersion and aggregation processes and certainly is an important criterion for study of the storage stability of these vesicles. ${ }^{9-10}$ Change in the lipid type, increased the absolute value of zeta-potential whereas in emulsomes, fats used trilaurin, tristearin, and comptriol ATO 888 provide a great negative value of zeta potential. ${ }^{9,10,14}$ Therefore, decrease in particle size and zeta potential due to high input energy during sonication provides stable and highly packed emulsomes. 


\section{APPLICATION OF EMULSOMES}

\section{Drug targeting}

One of the most useful aspects of emulsomes is their ability to target drugs. Emulsomes can be used to target drugs to the reticulo-endothelial system. The reticuloendothelial system preferentially takes up Emulsomes. The uptake of Emulsomal vesicles is controlled by circulating serum factors called opsonins. These opsonins mark the vesicles for clearance. Such localization of drugs is utilized to treat tumors in animals known to metastasize to the liver and spleen. This localization of drugs can also be used for treating parasitic infections of the liver. [74] Emulsomes can also be utilized for targeting drugs to organs other than the reticulo-endothelial system. A carrier system (such as antibodies) can be attached to vesicles totargetthemtospecificorgans. ${ }^{75}$

\section{Anti-neoplastic treatment}

Most antineoplastic drugs cause severe side effects. Emulsomes can alter the metabolism; prolong circulation and half life of the drug, thus decreasing the side effects of the drugs. Emulsomal entrapment of Methotrexate showed beneficial effects over the unentrapped drugs, such as decreased rate of proliferation of the tumor and higher plasma levels accompanied by slower elimination. [Table 2] shows various studies done on emulsomes as delivery system. ${ }^{76-77}$

\section{Leishmaniasis}

Leishmaniasis is a disease in which a parasite of the genus Leishmania invades the cells of the liver and spleen. Commonly prescribed drugs for the treatment are derivatives of antimony (antimonials), which in higher concentrations can cause cardiac, liver, and kidney damage. Use of emulsome in tests conducted showed that it was possible to administer higher levels of the drug without triggering the side effects, and thus allowed greater efficacy in treatment. ${ }^{78-79}$

\section{Use in Biotechnology}

Emulsomes are used in studying immune response due to their immunological selectivity, low toxicity, and greater stability. They are being used to study the nature of the immune response provoked by antigens. The in vitro permeation of estradiol from vesicular formulations through human stratum corneum was studied. The vesicles were composed of non-ionic n-alkyl polyoxyethylene ether surfactants. Two mechanisms are proposed to play an important role in vesicle-skin interactions, i.e., the penetration enhancing effect of surfactant molecules and the effect of the vesicular structures caused by their adsorption at the stratum corneum- suspension interface. ${ }^{80}$

\section{FUTURE ASPECTS}

Emulsomes are a promising approach for the formulation of drug compounds with poor aqueous solubility with varied oral bioavailability. The oral delivery of hydrophobic drugs can be made possible by emulsomes, which have been shown to substantially improve oral bioavailability. Renaissances in the use of emulsomes over the past few decades are inviting increasing attention. Recent trends are focused on the development of modified emulsomal solid or semisolid formulations as an alternative to the conventional liquid system. The development of emulsomes, however, is still largely empirical, and in vitro models that are predictive of oral bioavailability enhancement are lacking. There is a need for in vitro methods for predicting the dynamic changes involving the drug in the gut in order to monitor the solubilisation state of the drug in vivo. Attention also needs to be paid to the interactions between lipid systems and the pharmacologically active substance. The characteristics of various lipid formulations also need to be understood, so that guidelines can be established that allow identification of suitable candidate formulations at an early stage. Future research should involve human bioavailability studies as well as more basic studies on the mechanisms of action of this fascinating and diverse group of formulations.

\section{REFERENCES}

\begin{tabular}{|l|l|}
\hline$\underline{1 .}$ & $\begin{array}{l}\text { Arien A, Dupuy B. Encapsulation of calcitonin in liposomes depends in the vesicle } \\
\text { preparationmethod.JMicroencapsul1997;14:753-60. } \\
{[\text { PUBMED] }}\end{array}$ \\
\hline$\underline{2 .}$ & $\begin{array}{l}\text { Bangham AD, Standish MM, Watkins JC. Diffusion of univalent ions across the lamellae of swollen } \\
\text { phospholipids. J Mol Biol 1965;13:238-52. }\end{array}$ \\
\hline$\underline{3 .}$ & $\begin{array}{l}\text { Schreier H, Bouwstra J. Liposomes and niosomes as topical drug carriers: Dermal and transdermal drug delivery. J } \\
\text { Control Release 1994;30:1-15. }\end{array}$ \\
\hline$\underline{4 .}$ & $\begin{array}{l}\text { Humberstone AJ, Charman WN. Lipid-based vehicles for the oral delivery of poorly water soluble drugs. Adv Drug } \\
\text { Deliv Rev 1997;25:103-28 }\end{array}$ \\
\hline$\underline{5 .}$ & $\begin{array}{l}\text { Kim S. Liposomes as carriers of cancer chemotherapy and future aspects. Drugs 1993;46:618-38. } \\
{[\text { PUBMED] }}\end{array}$ \\
\hline$\underline{6}$. & $\begin{array}{l}\text { Zhu L, Huo Z, Wang L, Tong X, Xiao Y, Ni K. Targeted delivery of methotrexate to skeletal muscular tissue by } \\
\text { thermosensitive magnetoliposomes. Int J Pharm 2009;370:136-43. } \\
{[\text { PUBMED] }}\end{array}$ \\
\hline$\underline{7 .}$ & $\begin{array}{l}\text { Barber R, Shek P. Liposomes as a topical ocular drug delivery system. In: Rolland A, editor. Pharmaceutical } \\
\text { Particulate Carriers. New York: Marcel Dekker; 1993. p. 1-20. } ₹\end{array}$ \\
\hline
\end{tabular}




\begin{tabular}{|c|c|}
\hline$\underline{8 .}$ & $\begin{array}{l}\text { Singh SK, Rajera R, Nagpal K, Mishra DN. Niosomes: A controlled and novel drug delivery system. Biol Pharm } \\
\text { Bull 2011;34:945-53. } \\
\text { [PUBMED] }\end{array}$ \\
\hline 9. & $\begin{array}{l}\text { Vyas SP, Subhedar R, Jain S. Development and characterization of emulsomes for sustained and targeted delivery of } \\
\text { an antiviral agent to liver. J Pharm Pharmacol 2006;58:321-6. } 4 \\
\text { [PUBMED] }\end{array}$ \\
\hline 10. & $\begin{array}{l}\text { Paliwal R, Paliwal SR, Mishra N, Mehta A, Vyas SP. Engineered chylomicron mimicking carrier emulsome for } \\
\text { lymph targeted oral delivery of methotrexat. Int J Pharm 2009;380:181-8. }{ }^{\ddagger} \\
{[\underline{\text { PUBMED] }}}\end{array}$ \\
\hline 11. & $\begin{array}{l}\text { VanCott TC, Kaminski RW, Mascola JR, Kalyanaraman VS, Wassef NM, Alving CR, et al. HIV-1 neutralizing } \\
\text { antibodies in the genital and respiratory tracts of mice intranasally immunized with oligomeric gp160. J Immunol } \\
\text { 1998;160:2000-12. } ₫ \\
\text { [PUBMED] }\end{array}$ \\
\hline 12. & $\begin{array}{l}\text { Schwarz C, Mehnert W, Lucks JS, Muller RH. Solid lipid nanoparticles (SLNs) for controlled drug delivery: I. } \\
\text { Production, characterization and sterilization. J Control Release 1994;30:83-96. ^ }\end{array}$ \\
\hline 13. & $\begin{array}{l}\text { Vyas SP, Gupta S, Dube A. Antileishmanial efficacy of amphotericin b bearing emulsomes against experimental } \\
\text { visceral leishmaniasis. J Drug Target 2007;15:437-44. } 4\end{array}$ \\
\hline 14. & $\begin{array}{l}\text { Gupta S, Vyas SP. Development and characterization of Amphotericin B bearing emulsomes for passive and active } \\
\text { macrophage targeting. J Drug Target 2006;15:206-17. ^ }\end{array}$ \\
\hline 15. & $\begin{array}{l}\text { Weinstock PH, Bisgaier CL, Hayek T, Aalto-Setala K, Sehayek E, Sheiffele P, et al. Decreased HDL choesterol } \\
\text { levels but normal lipid absorption, growth and feeding behavior in apolipoprotein a-iv knockout mice. J Lipid Res } \\
\text { 1997;38:1782-94. } \\
\text { [PUBMED] }\end{array}$ \\
\hline 16. & $\begin{array}{l}\text { Ziv E, Bendayan M. Intestinal absorption of peptides through the enterocytes. Microsc Res Tech 2000;49:346-52. } \\
\text { [PUBMED] }\end{array}$ \\
\hline 17. & $\begin{array}{l}\text { Raybould HE. Nutrient tasting and signaling mechanisms in the gut. I. Sensing of lipid by the intestinal mucosa. Am } \\
\text { J Physiol 1999;277:G751-5. }\end{array}$ \\
\hline 18. & $\begin{array}{l}\text { Welling PG. Influence of food and diet on gastrointestinal drug absorption: A review. J Pharmacokinet Biopharm } \\
\text { 1977;5:292-334. } \\
\text { [PUBMED] }\end{array}$ \\
\hline 19. & $\begin{array}{l}\text { Porter CJH, Trevaskis NL, Charman WN. Lipids and lipid-based formulations: Optimizing the oral delivery of } \\
\text { lipophilic drugs. Nat Rev Drug Discov 2007;6:231-48. }\end{array}$ \\
\hline 20. & $\begin{array}{l}\text { Wagnera D, Spahn-Langguthb H, Hanafyb A, Koggela A, Langgutha P. Intestinal drug efflux: Formulation and food } \\
\text { effects. Adv Drug Deliv Rev 2001;50(supply 1):S13-31. }\end{array}$ \\
\hline 21. & $\begin{array}{l}\text { Brocks DR, Betageri GV. Enhanced oral absorption of halofantrine enantiomers after encapsulation in a } \\
\text { proliposomal formulation. J Pharm Pharmacol 2002;54:1049-53. } \\
\text { [PUBMED] }\end{array}$ \\
\hline 22. & $\begin{array}{l}\text { Hauss DJ. Oral lipid based formulations. Adv Drug Deliv Rev 2007;59:667- 76. } \\
\text { [PUBMED] }\end{array}$ \\
\hline 23. & $\begin{array}{l}\text { Hofmann AF, Borgstrom B. The intraluminal phase of fat digestion in man: The lipid content of the micellar and oil } \\
\text { phases of intestinal content obtained during fat digestion and absorption. J Clin Invest 1964;43:247-57. }\end{array}$ \\
\hline 24. & $\begin{array}{l}\text { Gursoy RN, Benita S. Self-emulsifying drug delivery systems (SEDDS) for improved oral delivery of lipophilic } \\
\text { drugs. Biomed Pharmacother 2004;58:173-82. } \\
\text { [PUBMED] }\end{array}$ \\
\hline 25. & $\begin{array}{l}\text { Pouton CW. Formulation of poorly water-soluble drugs for oral administration: Physicochemical and physiological } \\
\text { issues and the lipid formulation classification system. Eur J Pharm Sci 2006;29:278-87. } \\
\text { [PUBMED] }\end{array}$ \\
\hline 26. & $\begin{array}{l}\text { Chambin O, Jannin V. Interest of multifunctional lipid excipients: Case of Gelucire 44/14. Drug Dev Ind Pharm } \\
\text { 2005;31:527-34. } \\
\text { [PUBMED] }\end{array}$ \\
\hline 27. & $\begin{array}{l}\text { Gupta KS, Nappinnai M, Gupta VRM. Formulation and evaluation of topical meloxicam niosomal gel. Int J } \\
\text { Biopharm 2010;1:7-13. }\end{array}$ \\
\hline 28. & $\begin{array}{l}\text { Kulthe VV, Chaudhari PD. Solubility enhancement of etoricoxib by solid dispersions prepared by spray drying } \\
\text { technique. Int J Pharm Res } 2011 ; 45: 248-58 .\end{array}$ \\
\hline
\end{tabular}




\begin{tabular}{|c|c|}
\hline 29. & $\begin{array}{l}\text { Vilhemsen T, Eliasen H, Schaefer T. Effect of a melt agglomeration process on agglomerates containing solid } \\
\text { dispersions. Int J Pharma 2005;303:132-42. }\end{array}$ \\
\hline$\underline{30 .}$ & $\begin{array}{l}\text { Solid Fat Nanoemulsions As Drug Delivery Vehicles-Patent 5576016. Available from: } \\
\text { http://www.docstoc.com/docs/48874511/Solid-Fat-Nanoemulsions-As-Drug-Delivery-Vehicles-Patent-5576016. }\end{array}$ \\
\hline 31. & $\begin{array}{l}\text { Banerjee A, Roychoudhury J, Ali N. Stearylamine-bearing cationic liposomes kill leishmania parasites through } \\
\text { surface exposed negatively charged phosphatidylserine. J Antimicrob Chemother 2008;61:103-10. } \\
{[\underline{\text { PUBMED] }}}\end{array}$ \\
\hline 32. & $\begin{array}{l}\text { Sudhamani T, Priyadarisini N, Radhakrishna. Proniosomes-A promising drug carriers. Int J PharmTech Res } \\
\text { 2010;2:1446-54. } \quad\end{array}$ \\
\hline 33. & $\begin{array}{l}\text { Sek L, Porter CJH, Charman WN. Characterisation and quantification of medium chain and long chain triglycerides } \\
\text { and their in-vitrodigestion products, by HPTLC coupled with in situ densitometric analysis. J Pharm Biomed Anal } \\
\text { 2001;25:651-61. }\end{array}$ \\
\hline 34. & $\begin{array}{l}\text { Mujoriya R, Bodla RB, Dhamande K, Singh D, Patle L. Niosomal drug delivery system: The magic bullet. JAPS } \\
\text { 2011;1:20-3. }\end{array}$ \\
\hline 35. & $\begin{array}{l}\text { Ruckmani K, Sankar V. Formulation and optimization of zidovudine niosomes. AAPS PharmSciTech 2010;11:1119- } \\
\text { 27. } ₫ \\
\text { [PUBMED] }\end{array}$ \\
\hline$\underline{36 .}$ & $\begin{array}{l}\text { Venkatesan N, Vyas SP. Polysaccharide coated liposomes for oral immunization: Development and characterization. } \\
\text { Int J Pharm 2000;203:169-77. } ₫ \\
\text { [PUBMED] }\end{array}$ \\
\hline 37. & $\begin{array}{l}\text { Hofland HEJ, Boustra JA, Verhoef JC, Buckton G, Chowdry BZ, Ponec M, et al. Safety aspects of non-ionic } \\
\text { surfactant vesicles a toxicity study related to the physicochemical characteristics of non-ionic surfactants. J Pharm } \\
\text { Pharmacol 1992;44:287-94. }\end{array}$ \\
\hline 38. & $\begin{array}{l}\text { Hood E, Gonzalez M, Plaas A, Strom J, VanAuker M. Immunotargeting of nonionic surfactant vesicles to } \\
\text { inflammation. Int J Pharm 2007;339:222- 30. } ₫ \\
\text { [PUBMED] }\end{array}$ \\
\hline 39. & $\begin{array}{l}\text { Azeem A, Anwer MK, Talegaonkar S. Niosomes in sustained and targeted drug delivery: Some recent advances. J } \\
\text { Drug Target 2009;17:671-89. } 4 \\
\text { [PUBMED] }\end{array}$ \\
\hline 40. & $\begin{array}{l}\text { Barry BW. Novel mechanisms and devices to enable successful transdermal drug delivery. Eur J Pharm Sci } \\
\text { 2001;14:101-14. } 4 \\
\text { [PUBMED] }\end{array}$ \\
\hline 41. & $\begin{array}{l}\text { Devaraj GN, Parakh SR, Devraj R, Apte SS, Rao BR, Rambhau D. Release studies on niosomes containing fatty } \\
\text { alcohols as bilayer stabilizers instead of cholesterol. J Colloid Interface Sci 2002;251:360-5. } \\
\text { [PUBMED] }\end{array}$ \\
\hline 42. & $\begin{array}{l}\text { Kirby C, Clarke J, Gregoriadis G. Effect of cholesterol content of small unilamellar liposomes on their stability in } \\
\text { vivo and in vitro. Biochem J 1980;186:591-8. ^ } \\
\text { [PUBMED] }\end{array}$ \\
\hline 43. & $\begin{array}{l}\text { Harasym TO, Cullis PR, Bally MB. Intratumor distribution of doxorubicin following I.V. Administration of drug } \\
\text { encapsulated in egg phosphatidylcholine cholesterol liposomes. Cancer Chemother Pharmacol 1997;40:309-17. }\end{array}$ \\
\hline 44. & $\begin{array}{l}\text { Harder T, Simons K. Caveolae, digs, and the dynamics of sphingo-lipid cholesterol microdomains. Curr Opin Cell } \\
\text { Biol 1997;9:534-42. } \\
\text { [PUBMED] }\end{array}$ \\
\hline 45. & $\begin{array}{l}\text { Papahadjopoulos D, Cowden M, Kimelberg H. Role of cholesterol in membranes, effects on phospholipidprotein } \\
\text { interactions, membrane permeability and enzymatic activity. Biochim Biophys Acta 1973;330:8-26. } \\
\text { [PUBMED] }\end{array}$ \\
\hline 46. & $\begin{array}{l}\text { Snjezana S. PLGA nanoparticles prepared by nanoprecipitation: Drug loading and release studies of water soluble } \\
\text { drug. J Control Release 1999;57:171-85. }\end{array}$ \\
\hline 47. & $\begin{array}{l}\text { Ibrahim MMA, Sammour OA, Hammad MA, Megrab NA. In vitro evaluation of proniosomes gel as A drug carrier } \\
\text { for flurbiprofen. AAPS PharmSciTech 2008;9:782-90. }\end{array}$ \\
\hline 48. & $\begin{array}{l}\text { Fang JY, Hong CT, Chiu WT, Wang YY. Effect of liposomes and niosomes on skin permeation of enoxacin. Int J } \\
\text { Pharm 2001;219:61-72. }\end{array}$ \\
\hline
\end{tabular}




\begin{tabular}{|c|c|}
\hline & [PUBMED] \\
\hline 49. & $\begin{array}{l}\text { Dipali SR, Kulkarni SB, Betageri GV. Comparative study of separation of non-encapsulated drug from unilamellar } \\
\text { liposomes by various methods. J Pharm Pharmacol 1996;48:1112-5. } \\
\text { [PUBMED] }\end{array}$ \\
\hline$\underline{50 .}$. & Ljeoma FU, Vyas SP. Non-ionic surfactant based vesicles in drug delivery. Int J Pharm 1998;172:33-70. ^ \\
\hline$\underline{51 .}$. & $\begin{array}{l}\text { Szoka F, Papahadjopoulos D. Procedure for preparation of liposomes with large internal aqueous space and high } \\
\text { capture by reverse-phase evaporation. Proc Natl Acad Sci U S A 1978;75:4194-8. } \uparrow \\
{[\underline{\text { PUBMED] }}}\end{array}$ \\
\hline$\underline{52 .}$. & $\begin{array}{l}\text { Vemuri S, Rhodes CT. Preparation and characterization of liposomes as therapeutic delivery systems: A review. } \\
\text { Pharm Acta Helv 1995;70:95-111. } \\
\text { [PUBMED] }\end{array}$ \\
\hline$\underline{53 .}$. & $\begin{array}{l}\text { Balasubramaniam A, Kumar VA, Palliai KS. Formulation and in-vivo evaluation of niosomes encapsulated } \\
\text { daunorubicin hydrochloride. Drug Dev Ind Pharm 2002;28:1181-93. }\end{array}$ \\
\hline$\underline{54 .}$ & $\begin{array}{l}\text { Hope MJ, Bally MB, Webb G, Cullis P. Production of large unilamellar vesicles by rapid extrusion procedure: } \\
\text { Characterization of size distribution, trapped volume, and ability to maintain a membrane potential. Biochim } \\
\text { Biophys Acta 1985;812:55-65. }\end{array}$ \\
\hline$\underline{55 .}$ & $\begin{array}{l}\text { Batzri S, Korn ED. Single bilayer liposomes prepared without sonication. Biochim Biophys Acta 1973;298:1015- } \\
\text { 9. } \quad \text { } \\
\text { [PUBMED] }\end{array}$ \\
\hline$\underline{56 .}$ & $\begin{array}{l}\text { Fry DW, White JC, Goldman ID. Rapid separation of low molecular weight solutes from liposomes without dilution. } \\
\text { Anal Biochem 1978;90:809-15. } 5 \\
{[\underline{\text { PUBMED] }}}\end{array}$ \\
\hline$\underline{57 .}$ & $\begin{array}{l}\text { Dayan N, Touitou E. Carriers for skin delivery of Trihexyphenidyl } \mathrm{HCl} \text { : Ethosomes vs. Liposomes. Biomaterials } \\
\text { 2000;21:1879-85. } \\
\text { [PUBMED] }\end{array}$ \\
\hline$\underline{58 .}$. & $\begin{array}{l}\text { Sugarman SM, Zou YY, Wasan K, Poirot K, Kumi R, Reddy S, et al. Lipid-complexed camptothecin: Formulation } \\
\text { and initial biodistribution and anti-tumor activity studies. Cancer Chemother Pharmacol 1996;37:531-8. }\end{array}$ \\
\hline$\underline{59 .}$. & $\begin{array}{l}\text { Vemuri S, Yu C, Wangsatorntanakun V, Roosdorp N. Large-scale production of liposomes by Microfluidizer. Drug } \\
\text { Dev Ind Pharm 1990;16:2243-56. ^ }\end{array}$ \\
\hline$\underline{60 .}$ & $\begin{array}{l}\text { Kremer JM, Esker MW, Pathmamanoharan C, Wiersema PH. Vesicles of variable diameter prepared by a modified } \\
\text { injection method. Biochemistry 1977;16:3932-5. } \\
\text { [PUBMED] }\end{array}$ \\
\hline$\underline{61 .}$ & $\begin{array}{l}\text { Lundberg BB. Biologically active comptothecin derivatives for incorporation into liposomes bilayers and lipid } \\
\text { emulsion. Anticancer Drug Des } 1988 ; 13: 453-61 \ldots\end{array}$ \\
\hline$\underline{62 .}$ & $\begin{array}{l}\text { Pons M, Foradada M, Estelrich J. Liposomes obtained by the ethanol injection method. Int J Pharm 1993;95:51- } \\
6 .\end{array}$ \\
\hline$\underline{63 .}$ & $\begin{array}{l}\text { Stano P, Bufali S, Pisano C, Bucci F, Barbarino M, Santaniello M, et al. Novel camptothecin analogue (Gimatecan)- } \\
\text { containing liposomes prepared by the ethanol injection method. J Liposome Res 2004;14:87- 109. } \\
\text { [PUBMED] }\end{array}$ \\
\hline 64. & $\begin{array}{l}\text { Campbell MJ. Lipofection reagents prepared by simple ethanol injection technique. Biotechniques 1995;18:1027- } \\
\text { 32. } ~ \\
\text { [PUBMED] }\end{array}$ \\
\hline 65. & $\begin{array}{l}\text { Domazou A, Luisi PL. Size distribution of spontaneously formed liposomes by the alcohol injection method. J } \\
\text { Liposome Res 2002;12:205- } 20 . \text {. }\end{array}$ \\
\hline 66. & $\begin{array}{l}\text { Kagawa Y, Racker E. Partial resolution of the enzymes catalyzing oxidative phosphorylation. J Biol Chem } \\
1971 ; 246: 5477-87 . \quad .\end{array}$ \\
\hline 67. & $\begin{array}{l}\text { Milsmann MHW, Schwendner RA, Weder H. The preparation of large single bilayer liposomes by a fast and } \\
\text { controlled dialysis. Biochim Biophys Acta 1978;512:147-55. } 4\end{array}$ \\
\hline 68. & $\begin{array}{l}\text { Enoch HAG. Strittmatter P. Formation and properties of } 1000 \text { A diameter, single-bilayer phospholipid vesicles. Proc } \\
\text { Natl Acad Sci U S A 1979;76:145-9. ^ }\end{array}$ \\
\hline 69. & $\begin{array}{l}\text { Porter CJH, Charman WN. Uptake of drugs into the intestinal lymphatics after oral administration. Adv Drug Deliv } \\
\text { Rev 1997;25:71-89. }\end{array}$ \\
\hline 70 . & 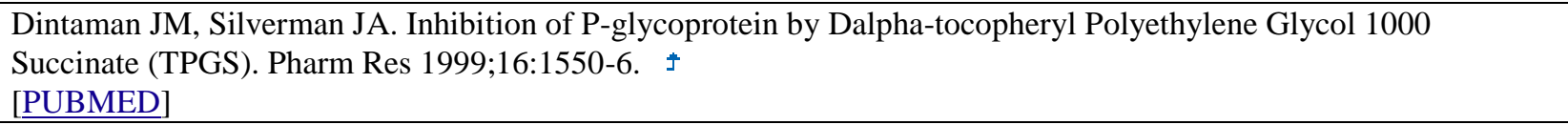 \\
\hline 71. & $\begin{array}{l}\text { Nerurkar MM, Burton PS, Borchardt RT. The use of Surfactants to Enhance the Permeability of Peptides Through } \\
\text { Caco-2 Cells by Inhibition of An Apically Polarized Efflux System. Pharm Res 1996;3:528-34. } ₫\end{array}$ \\
\hline
\end{tabular}




\begin{tabular}{|c|c|}
\hline 72. & $\begin{array}{l}\text { Aungst BJ. Intestinal permeation enhancers. J Pharm Sci 2000;89:429-42. ^ } \\
\text { [PUBMED] }\end{array}$ \\
\hline 73. & $\begin{array}{l}\text { Muranishi S. Absorption enhancers. Crit Rev Ther Drug Carrier Syst 1990;7:1-33. ^ } \\
\text { [PUBMED] }\end{array}$ \\
\hline 74. & $\begin{array}{l}\text { Erion MD, Van Poelje PD, Mackenna DA, Colby TJ, Montag AC, Fujitaki JM, et al. Liver-targeted drug delivery } \\
\text { using hepdirect prodrugs. J Pharmacol Exp Ther 2005;312:554-60. } \\
\text { [PUBMED] }\end{array}$ \\
\hline 75. & $\begin{array}{l}\text { Banerjee G, Nandi G, Mahato SB, Pakrashi A, Basu MK. Drug delivery system: Targeting of pentamidines to } \\
\text { specific sites using sugar-grafted liposomes. J Antimicrob Chemother1996;38:145-50. } \\
\text { [PUBMED] }\end{array}$ \\
\hline 76. & $\begin{array}{l}\text { Moghbel A, Zand Moghaddam A, Rezaee S, Pedram M. High performance liquid chromatography determination of } \\
\text { methotrexate in plasma. Iran J Pharm Res } 2003 ; 2: 149-52 \text {. }\end{array}$ \\
\hline 77. & $\begin{array}{l}\text { Goldsmith DR, Perry CM. Amphotericin B lipid complex: In visceral leishmaniasis. Drugs 2004;64:1905-11. ^ } \\
\text { [PUBMED] }\end{array}$ \\
\hline 78. & $\begin{array}{l}\text { Kole L, Sakar K, Mahato SB, Das PK. Neoglycoprotein conjugated liposomes as macrophage specific drug carrier in } \\
\text { the therapy of leishmaniasis. Biochem Biophys Res Commun 1994;200:351-8. } \\
{[\underline{\text { PUBMED] }}}\end{array}$ \\
\hline 79. & $\begin{array}{l}\text { Sanchez-Brunete JA, Dea MA, Rama S, Bolas F, Alunda JM, Raposo R, et al. Treatment of experimental visceral } \\
\text { leishmaniasis with amphotericin B in stable albumin microspheres. Antimicrobial AgentsChemother 2004;48:3246- } \\
\text { 52. }\end{array}$ \\
\hline 80 . & $\begin{array}{l}\text { Lowell GH, Kaminski RW, VanCott TC, Slike B, Kersey K, Zawoznik E, et al. Proteosomes, emulsomes, and } \\
\text { cholera Toxin B Improve nasal immunogenicity of human immunodeficiency virus Gp160 in mice: Induction of } \\
\text { serum, intestinal, vaginal, and Lung IgA and IgG. J Infect Dis 1997;175:292-301. ^[PUBMED] }\end{array}$ \\
\hline
\end{tabular}

